\title{
Gross anatomy and ultrasonography of the udder in goat
}

\author{
ADAM, Z. E. A. S. ${ }^{1}$, RAGAB, G. A. N. ${ }^{2}$, AWAAD, A. S. ${ }^{1}$, TAWFIEK, M. G. ${ }^{1}$ and \\ MAKSOUD, M. K. M. A. ${ }^{1 *}$ \\ ${ }^{1}$ Anatomy and Embryology Department, Faculty of Veterinary Medicine, Beni-Suef University, Beni-Suef 62511, Egypt \\ ${ }^{2}$ Surgery, Anesthesiology, and Radiology Department, Faculty of Veterinary Medicine, Beni-Suef University, \\ Beni-Suef 62511, Egypt \\ *E-mail: mkamalvet@gmail.com
}

\begin{abstract}
Introduction: The udder is a very important structural and physiological component in all dairy animals, so the precise knowledge of its normal gross morphology is fundamental for the clinical examination. Objective: The current study aimed to clarify the gross anatomical characteristics and ultrasonographic findings of the udder in Egyptian native breeds of goat (Baladi goat). Materials and Methods: Thirteen healthy Baladi goats during lactation period were grossly investigated and then they were examined through B-mode ultrasonography. Two specimens were used for corrosion casting and the remaining specimens were subjected to the anatomical dissection. Results: The gross anatomical investigation revealed that the udder of goat was consisted of two halves; each one had mammary body and teat, and it was suspended in the ventral abdominal wall and pelvic floor through the medial and lateral suspensory laminae. Moreover, each half was composed of a single mammary unit which included the mammary glandular parenchyma, lactiferous ducts, lactiferous sinus and teat canal ended by a teat orifice. These mammary structures showed variant echogenicity during ultrasonographic examination according to their reflective intensity to the ultrasound. Conclusion: The morphological features and ultrasonographic findings obtained in this study could assist in the further diagnosis of several pathological conditions of the udder of goat.
\end{abstract}

Keywords: goat, udder, gross anatomy, ultrasonography.

\section{Introduction}

There is a growing awareness in many countries for using the goat as an efficient animal for milk production (ABU, MHOMGA and AKOGWU, 2013). Recently, the goat became an important aspect of animal production in Egypt as it is considered a source of meat, milk and hide (HAMED, MABROUK, SHAAT et al., 2009). Preserving normal physiological function of the mammary gland is important for production of high-quality milk and healthy offspring (CONTRERAS, SIERRA, SANCHEZ et al., 2007). This importance deserves establishment of more accurate and specific studies about the gross anatomy of the udder in this animal.

The negative economic impact of the loss of milk production due to mammary gland illness necessitates developing of fast and accurate diagnostic techniques. Ultrasonography is a non-invasive and accurate method used for diagnosis of several physiological and pathological conditions of the mammary gland in ruminants (WOJTOWSKI, SLOSARZ, JUNKUSZEW et al., 2006; SLOSARZ, WOJTOWSKI, BIELINSKA et al., 2010; DAR, TIWARI, JHALA et al., 2014). The imaging technique depends on the intensity of the sound reflection between the closely related structures, the terms hyper-echoic (high intensity), hypo-echoic (low intensity) and anechoic (no intensity) are used for ultrasonographic characterization of these morphological structures of the mammary gland (DESCOTEAUX, GNEMMI and COLLOTON, 2010).

\section{Materials and Methods}

\subsection{Gross examination}

The gross examination (position, form and shape) of the udder was recorded in healthy Egyptian Baladi female goats during lactation period ( $\mathrm{n}=13$, age $2-5$ years, weight $18-27 \mathrm{kgs}$ ) which purchased alive from the animals' markets in Beni-Suef Governorate.

\subsection{Ultrasonographic examination}

After a thorough cleansing of the udder and teat with tap-water, they were carefully prepared for ultrasonographic imaging. The mammary glandular parenchyma, lactiferous ducts, glandular sinus and the annular fold between glandular and teat sinuses were examined using direct contact method, where the convex probe of $5 \mathrm{MHz}$ frequency was horizontally placed on the udder skin after application of a contact gel (FASULKOV, GEORGIEV, ANTONOV et al., 2010). The teat was examined through water bath technique, where it was immersed into a plastic cup filled with warm water and a linear probe of $8.5 \mathrm{MHz}$ frequency was vertically placed in contact with a plastic cup or inside it (FASULKOV, YOTOV, ATANASOV et al., 2013).

\subsection{Dissection of the specimens}

Eleven fresh cadavers were injected with the embalming solution through the common carotid artery (2\% Formalin $40 \%, 2 \%$ concentrated liquid phenol, 20\% Ethyl alcohol 95\%, $6 \%$ Glycerin and $70 \%$ water), then the specimens were kept in formalin $10 \%$ for 7 days. The specimens were eviscerated 
and carefully dissected in both sides for demonstration of the suspensory apparatus and internal structure of the udder (HILDEBRAND, 1968).

\subsection{Preparation of the corrosion cast specimens}

Two fresh udder specimens were injected with colored gum-milk latex and they were kept in the refrigerator for 3 days. The cured specimens were macerated in hot water for 2 weeks. The cast was checked daily and was gently rinsed with tap-water until it became free from the macerated tissues.

The nomenclatures in this study were adopted according to Nomina Anatomica Veterinaria (INTERNATIONAL..., 2012).

\section{Results}

The udder of goat was located in the inguinal region. Its dorsal aspect appeared as a single glandular mass and it was divided into two halves by a well-defined median inter-mammary

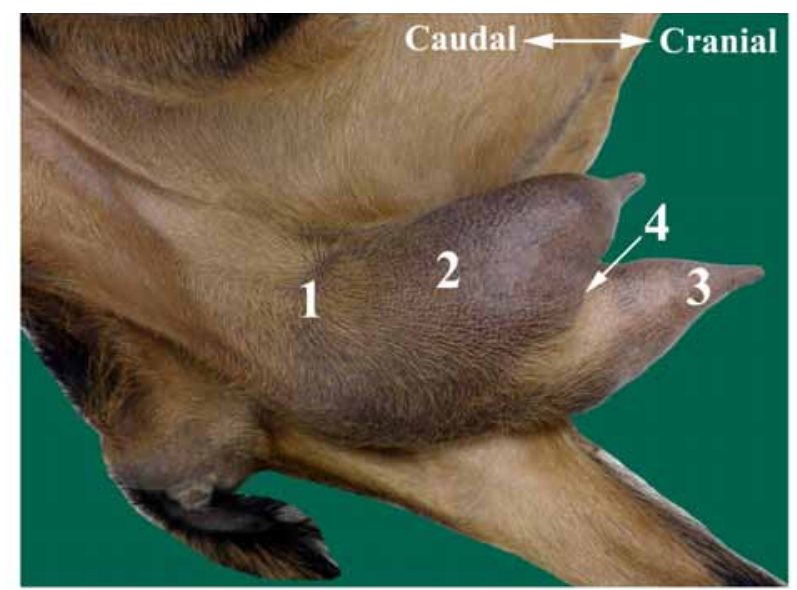

Figure 1. A photograph of an adult female goat in lateral recumbency, showing the udder in the inguinal region. (1) Base of the udder; (2) Lateral surface of the mammary body; (3) Teat; (4) Inter-mammary groove.

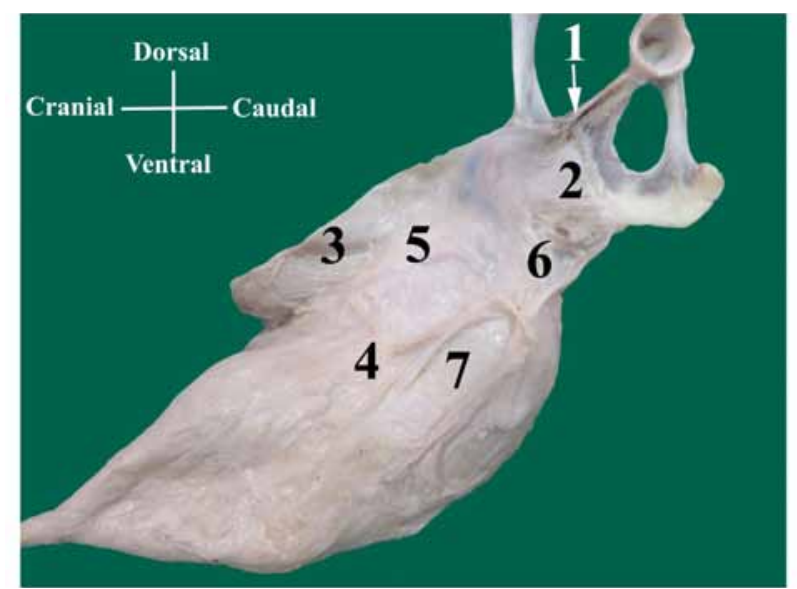

Figure 2. A photograph of the dissected lateral aspect of the udder of goat connected to the pelvic floor and separated from the abdominal wall showing. (1) Pre-pubic tendon; (2) Symphysial tendon; (3) Ventral abdominal wall; (4) Lateral suspensory lamina opened longitudinally; (5) Attachment of the lateral lamina to the abdominal wall; (6) Attachment of the lateral lamina to the symphysial tendon; (7) Glandular tissue of the udder. groove. Each half was composed of mammary body and teat. The mammary body appeared conical in shape and its base was slightly concave and slopped cranioventrally in adaptation to the ventral abdominal wall. The lateral surfaces were convex and they were covered by a movable skin and fine hairs, while the medial surfaces were flattened (Figure 1).

The udder was attached to the ventral abdominal wall and pelvic floor through the medial and lateral suspensory laminae. Taking the pre-pubic tendon as a boundary, each lamina was classified into abdominal and pelvic parts. The lateral lamina was a double plate, its abdominal part was attached to the ventral abdominal wall by the aponeurosis of the external abdominal oblique muscle for about $12.75 \pm 1.19 \mathrm{~cm}$, while the pelvic one was smaller, and it was attached to the pelvic floor by means of the symphsyial tendon for about $3.07 \pm 0.25 \mathrm{~cm}$. The lateral lamina continued ventrally to cover the lateral surface of the udder till the level of the base of the teat (Figure 2).

Using the direct contact technique (trans-cutaneus echo-graph) with $5 \mathrm{MHz}$ and convex probe enabled visualization of these laminae. The skin and lateral suspensory lamina were visualized as a hyper-echoic line, from this lamina several hypo-echoic suspensory lamellae were detached dividing the mammary gland parenchyma into lobes which appeared as a hyper-echoic structure (Figure 3).

The medial suspensory lamina was a double plate located on the medial aspects of both halves of the udder. Its abdominal part was attached to the ventral abdominal wall by the tunica falva abdominalis on both sides of the linea alba for about $11.34 \pm 0.80 \mathrm{~cm}$, while, the pelvic part was smaller and attached to the pelvic floor by means of the symphsyial tendon for about $3.14 \pm 0.17 \mathrm{~cm}$ (Figure 4 ). Through application of the convex probe at the level of the intermammary groove, the medial suspensory laminae were detected as two hyper-echoic lines separating between the two halves of the udder (Figure 5).

The dorsal section and corrosion casting of the udder of goat (Figures 6 and 7 ) showed that each half was composed of a single mammary unit which included the mammary

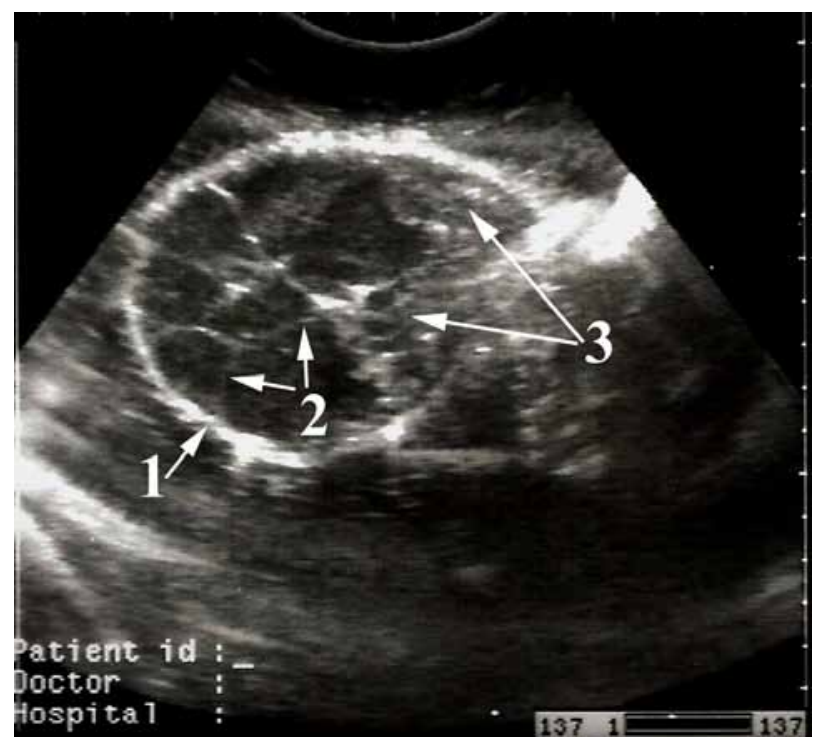

Figure 3. Ultrasound image of the mammary glandular parenchyma of lactating goat (Direct contact technique, horizontal scan, $5 \mathrm{MHz}$ convex probe) showing. (1) Skin and lateral suspensory lamina; (2) Suspensory lamellae; (3) Lobes of the mammary gland. 


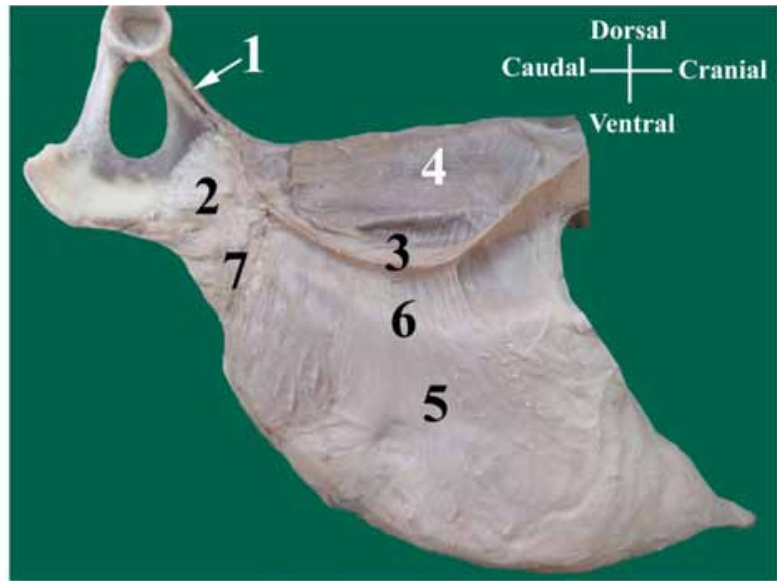

Figure 4. A photograph of the dissected medial aspect of the udder of goat connected to the pelvic floor and separated from the abdominal wall showing. (1) Pre-pubic tendon; (2) Symphysial tendon; (3) Ventral abdominal wall; (4) Rectus abdominis muscle; (5) Medial suspensory lamina; (6) Attachment of the medial supensory lamina to the ventral abdominal wall; (7) Attachment of the medial suspensory lamina to the symphysial tendon.

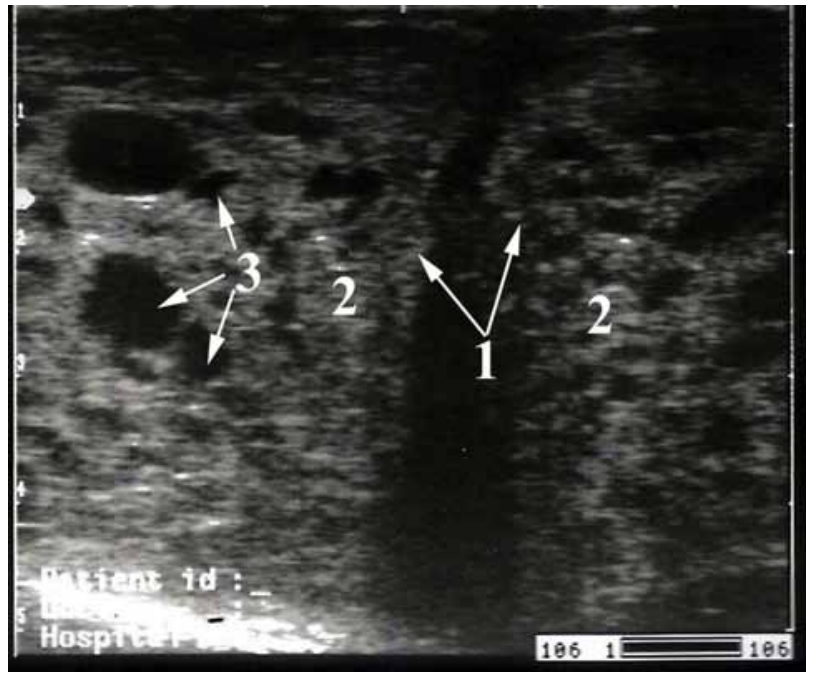

Figure 5. Ultrasound image of the mammary glandular parenchyma of lactating goat (Direct contact technique, horizontal scan, $5 \mathrm{MHz}$ convex probe) showing. (1) Septum between the two halves of the gland representing the medial suspensory laminae; (2) Glandular parenchyma of the two halves of the gland; (3) Small lactiferous ducts or blood vessels.

glandular parenchyma, duct system and cavity system. The mammary glandular parenchyma was constituted by the lobulated lactiferous tissue aggregation at the base of each half. The lactiferous ducts appeared as holes and they open irregularly into the corresponding sinus. The internal layer of the duct system had slightly elevated folds which separated between the lactiferous ducts; these folds either extended for a short distance or reached the level of the lactiferous sinus. The glandular parenchyma within each half appeared as a homogenous hyper-echoic structure with anechoic zones which might refer to the small lactiferous ducts or the blood vessels (Figure 5). The large lactiferous ducts were distinguished from the blood vessels as the former were visualized as anechoic branches opened into the glandular sinus (Figure 8 ). The cavity

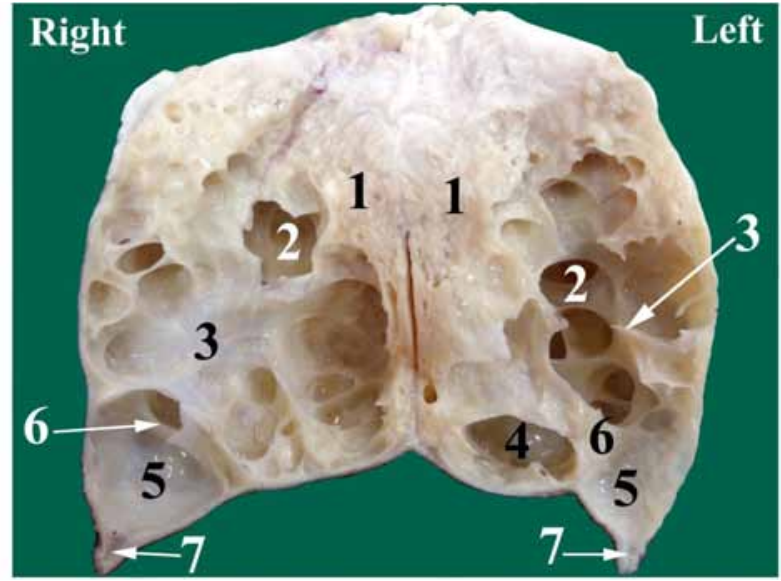

Figure 6. A photograph of the udder of goat showing a dorsal section at the level of the teat. (1) Glandular tissue of the udder; (2) Lactiferous ducts; (3) Elevated folds between the lactiferous ducts; (4) Glandular part of the lactiferous sinus; (5) Papillary part of the lactiferous sinus; (6) Annular fold between the two parts of lactiferous sinus; (7) Teat canal.

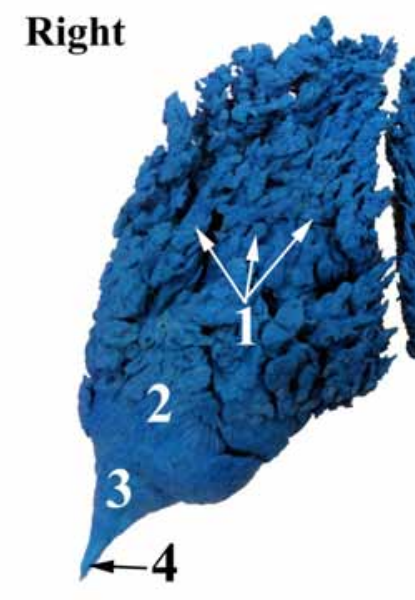

Left

Figure 7. A photograph of corrosion casting of the udder of goat showing. (1) Lactiferous ducts; (2) Glandular part of the lactiferous sinus; (3) Papillary part of the lactiferous sinus; (4) Teat canal.

of the mammary gland included the teat canal and lactiferous sinus. The latter was incompletely divided by an annular fold into glandular and papillary parts. The glandular part of the lactiferous sinus was a wide irregular pouch received the openings of the lactiferous ducts. This glandular sinus was detected as anechoic space, while its wall appeared as mixed hypo-hyper-echoic folds (Figure 8). The annular fold separating between glandular and teat sinuses appeared as a hypo-echoic linear structure (Figure 9).

The teat was funnel in shape with wide base and narrow apex, and it directed cranioventrally and slight laterally (Figure 1). The teat sinus was funnel shaped cavity, while the teat canal was a small narrow passage for about $4.01 \pm 0.55 \mathrm{~mm}$, it was lined by fine longitudinal ridges, and it ended by a teat orifice (Figure 10). These papillary structures were visualized using the water bath technique and $8.5 \mathrm{MHz}$ linear probe that produced a good quality image, while, using the direct contact technique with a lower frequency $(5 \mathrm{MHz})$ produced an unsatisfactory 


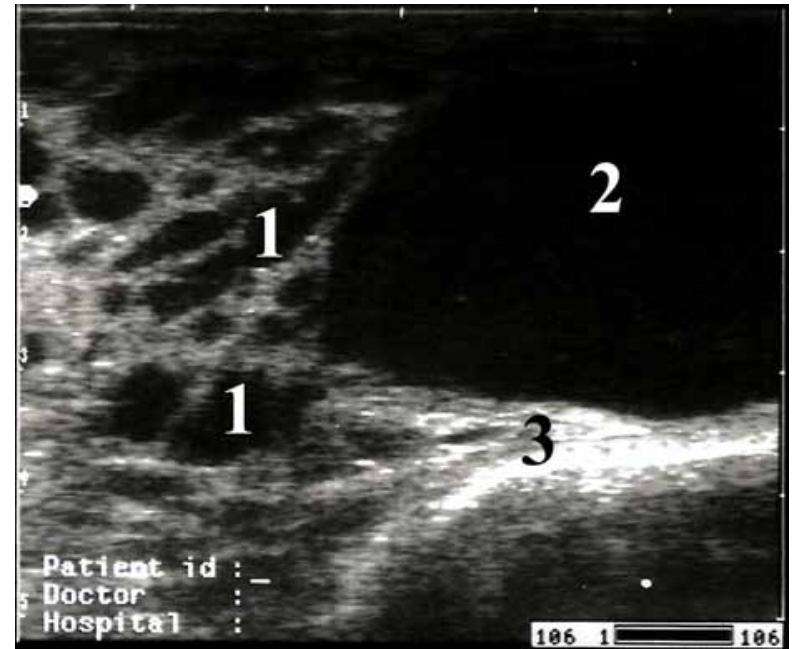

Figure 8. Ultrasound image of the mammary gland of lactating goat showing the lactiferous ducts open in the glandular sinus (Direct contact technique, horizontal scan, $5 \mathrm{MHz}$ convex probe). (1) Large lactiferous ducts; (2) Glandular sinus; (3) Wall of the glandular sinus.

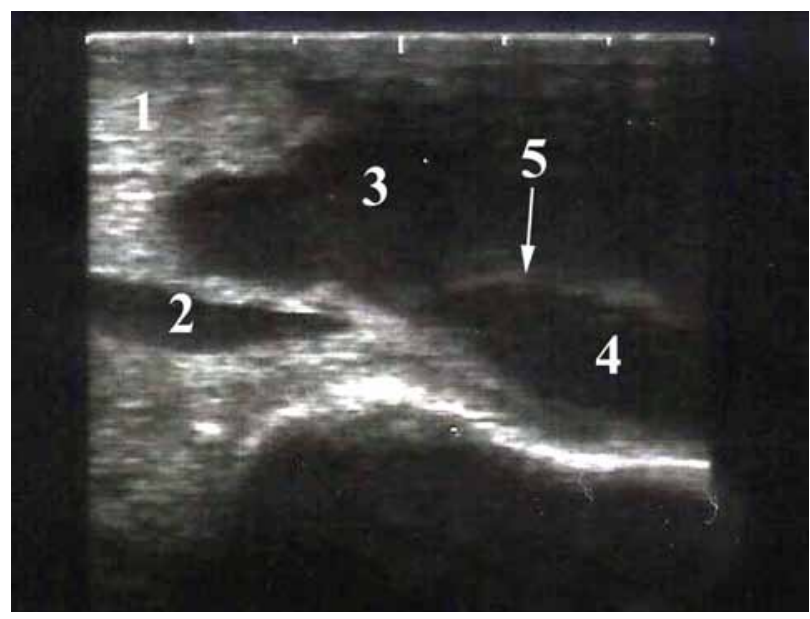

Figure 9. Ultrasound image of the mammary gland of lactating goat showing the transition between the glandular and teat sinuses (Direct contact technique, horizontal scan, $5 \mathrm{MHz}$ convex probe). (1) Glandular parenchyma; (2) Large lactiferous duct; (3) Glandular sinus; (4) Teat sinus; (5) An annular fold between 3 and 4.

image. The teat wall was differentiated into three layers; the outer layer appeared as a hyper-echoic line, the middle one was a hypo-echoic, while the inner layer appeared as hyper-echoic. The teat orifice appeared as an anechoic structure at the tip of the teat. The teat canal was visualized as an anechoic lumen surrounded by two hyper-echoic layers. The echo-graphic visualization of the transitional area between the teat sinus and teat canal was a hypo-echoic structure. The lumen of the teat sinus was detected as anechoic area (Figure 11).

\section{Discussion}

The gross morphology of the udder of goat was described in this study according to Moussa (2003) and Atyia (2009) in the same animal and Konig and Liebich (2009) and Dyce, Sack, and Wensing (2010) in ruminants.

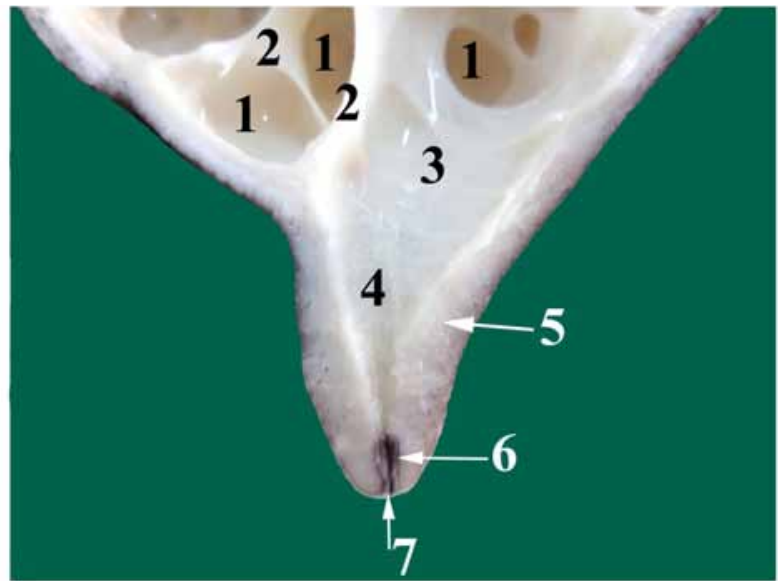

Figure 10. A photograph of the udder of goat showing a dorsal section of the teat. (1) Lactiferous ducts; (2) Elevated folds between the lactiferous ducts; (3) Glandular part of the lactiferous sinus; (4) Papillary part of the lactiferous sinus; (5) Teat wall; (6) Teat canal; (7) Teat orifice.

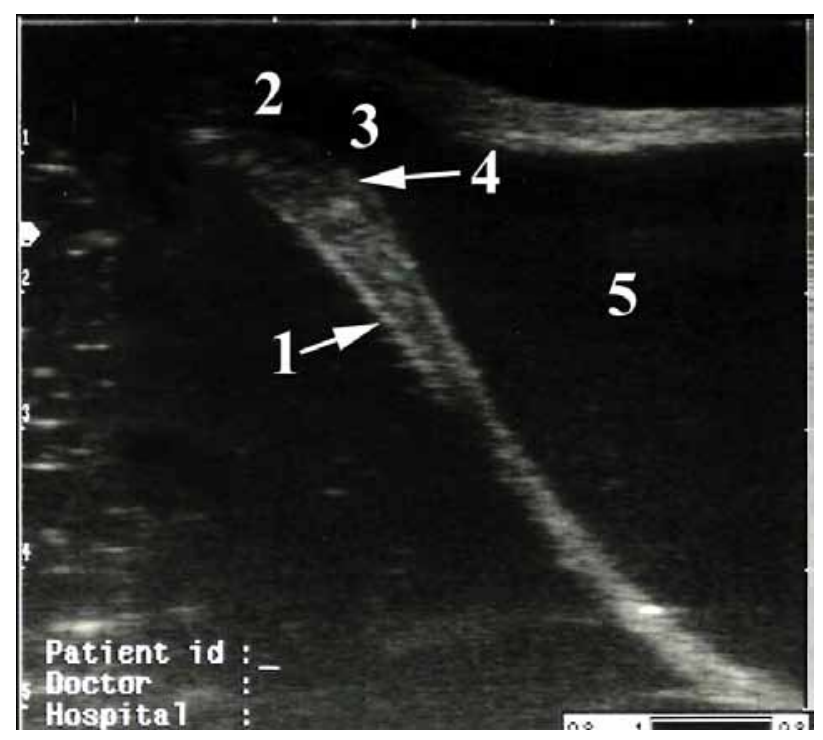

Figure 11. Ultrasound image showing the teat of lactating goat (water bath technique, vertical scan, $8.5 \mathrm{MHz}$ linear probe); (1) Teat wall; (2) Teat orifice; (3) Teat canal; (4) Transition area between the teat sinus and teat canal (rosette of Furstenberg); (5) Teat sinus.

The present study and Budras, Habel, Wunsche et al. (2003) in cow asserted that the abdominal part of the lateral suspensory lamina was attached to the ventral abdominal wall by the aponeurosis of the external abdominal oblique muscle. On the other hand, this part was derived either from the linea alba in goat (GARRETT, 1988) or from the medial femoral fascia in ewe (MAY, 1971). Moreover, the pelvic part of this lamina was attached to the pelvic floor through the symphysial tendon, similarly to the findings of Garrett (1988) in goat, May (1971) in ewe and Budras, Habel, Wunsche et al. (2003) in cow. However, Constantinescu (2001) in goat and Hussain, Lone and Moulvi (2009) in cow reported the origin of the lateral suspensory lamina from the symphysial tendon.

Concerning the medial suspensory lamina of goat's udder, its abdominal part was derived from the tunica flava abdominalis, 
while its pelvic part was attached to the pelvic floor through the symphysial tendon. Such findings were similar to the results of Constantinescu (2001) in goat, May (1971) in ewe, Jalakas, Saks and Klaassen (2000) in cow and Smuts and Bezuidenhout (1987) in she-camel. On the other hand, the medial suspensory lamina was derived from the tunica flava abdominalis along the caudal part of the linea alba (GARRETT, 1988 in goat; SMALLWOOD, 1993 in cow).

Similarly to the results of Fasulkov, Georgiev, Antonov et al. (2010) and Fasulkov, Yotov, Atanasov et al. (2013) in goat, the trans-cutaneus teat echo-graph with a low frequency $(5 \mathrm{MHz})$ linear probe produced an unsatisfactory image. On the other hand, Seeh, Hospes and Bostedt (1996) in cow reported a good quality image through using the direct contact of the teat with lower frequency transducer probe $(3.5$ or $5 \mathrm{MHz})$.

The current study highlighted the normal echo-graphic appearance of the suspensory laminae of the udder of goat; the medial suspensory laminae were visualized as hyper-echoic lines separating between the two halves of the udder, while the lateral lamina appeared as a hyper-echoic line which detached hypo-echoic suspensory lamellae dividing the mammary gland parenchyma into lobes.

The current investigation reported a homogenous hyper-echoic mammary gland parenchyma with anechoic zones which might refer to small lactiferous ducts or the blood vessels; the large lactiferous ducts were differentiated from the blood vessels as the former appeared as anechoic branches opened into the glandular sinus. The same findings were observed by Fasulkov, Georgiev, Antonov et al. (2010) in goat, Rambabu, Sreenu, Kumar et al. (2009) in buffalo and Abshenas, Sajjadian and Taghavi (2014) in mare.

Fasulkov, Georgiev, Antonov et al. (2010) attributed the anechoic appearance of the lactiferous sinus to presence of the milk inside this sinus. The wall of glandular sinus appeared as mixed hyper-hypo-echic folds as proved by Ragab, Saleh, Ahmed et al. (1999) in goat, Abshenas, Vosough, Masoudifard et al. (2007) in she camel. However, Hallowell (2012) in cow reported that the glandular sinus is bounded by a hyper-echoic mucosa. The annular fold separating between the glandular and teat sinuses was visualized as a hypo-echoic linear structure. On the other hand, this fold appears either an anechoic zone (FASULKOV, YOTOV, ATANASOV et al., 2013 in goat; FASULKOV, VASILEV, KARADAE et al., 2014 in cow) or a hyper-echoic linear structure (RAGAB, SALEH, AHMED et al., 1999 in goat; ABSHENAS, VOSOUGH, MASOUDIFARD et al., 2007 in she camel).

The teat echo-graph showed three layers of the teat wall; the outer layer appeared as a hyper-echoic line, the middle one was a hypo-echoic, while the inner layer was a hyper-echoic as reported by Dar, Tiwari, Jhala et al. (2014) in goat, Hallowell (2012) in cow, Rambabu, Sreenu, Kumar et al. (2009) in buffalo and Abshenas, Sajjadian and Taghavi (2014) in mare. The teat orifice of goat appeared as a small anechoic structure at the tip of the teat canal as emphasized by Fasulkov, Yotov, Atanasov et al. (2013) in the same animal and Abshenas, Sajjadian and Taghavi (2014) in mare. Meanwhile, Sendag and Dinc (1999) in cow established it as a hyper-echoic structure.

The teat canal visualized in this investigation was an anechoic lumen surrounded by two hyper-echoic layers in matching the findings of Ragab, Saleh, Ahmed et al. (1999) and Qutp (2014) in goat. On the other hand, it is observed as a hyper-echoic line surrounded on both sides by parallel and thick hypo-echoic zones in goat (FASULKOV, YOTOV, ATANASOV et al., 2013) and buffalo (RAMBABU, SREENU, KUMAR et al., 2009).

The transition between the teat canal and teat sinus is designated as the rosette of Furstenberg (ASTI, KURTDEDE, ALTUNAY et al., 2011). This structure was visualized as a hypo-echoic as proved by Fasulkov, Yotov, Atanasov et al. (2013) in goat, Fasulkov, Vasilev, Karadae et al. (2014) in cow and Abshenas, Sajjadian and Taghavi (2014) in mare. However, it is visualized as a hyper-echoic circular area in the center of the teat of buffalo (RAMBABU, SREENU, KUMAR et al., 2009). On the other hand, it is unclear and not perceptible in goat (DAR, TIWARI, JHALA et al., 2014) and she camel (ABSHENAS, VOSOUGH, MASOUDIFARD et al., 2007).

\section{Conclusion}

The morphological structures of the udder of goat were grossly described and they were examined through two methods of the ultrasonography, water bath method for the teat and direct contact method for the mammary structures other than the teat. The given results could help as a guide for the further ultrasonographic researches into several pathological conditions of the udder of goat, regarding application of more accurate diagnosis.

\section{References}

ABSHENAS, J., VOSOUGH, D., MASOUdIFARD, M. and MOLAI, M.M. B-mode ultrasonography of the udder and teat in camel (Camelus dromedaries). Journal of Veterinary Research, 2007, vol. 62, n. 2, p. 27-31.

ABSHENAS, J., SAJJADIAN, SM. and TAGHAVI, M. Ultrasonographic examination of mammary glands in Caspian mares during the lactation and dry period. Iranian Journal of Veterinary Surgery, 2014, vol. 9, n. 1, p. 37-43.

ABU, AH., MHOMGA, LI. and AKOGWU, EI. Assessment of udder characteristics of West African Dwarf (WAD) goat reared under different management systems in Makurdi, Benue State, Nigeria. African Journal of Agricultural Research, 2013, vol. 8, n. 25, p. 3255-3258.

ASTI, RN., KURTDEDE, N., ALTUNAY, H., ALBAY, B., OZEN, A. and BAYRAKTAROGLU, A.G. Histological and immunohistochemical studies on the Furstenberg's rosette in cow. Kafkas Üniversitesi Veteriner Fakültesi Dergisi, 2011, vol. 17, n. 2, p. 223-228.

ATYIA, MA. Anatomical, histological and radiological study of the mammary gland of the small ruminants. Bas J Vet Res, 2009, vol. 8, n. 2, p. 10-22.

BUDRAS, KD., HABEL, RE., WUNSCHE, A. and BUDA, S. Bovine anatomy, an illustrated text. lst ed. Hannover: Schlutersche Gmbh, 2003. p. $88-91$.

CONSTANTINESCU, GH. Guide to regional anatomy based on the dissection of the goat. 1st ed. USA: Iowa State University Press, 2001. p. 122-123.

CONTRERAS, A., SIERRA, D., SANCHEZ, A., CORRALES, J., MARCO, J., PAAPE, M. and GONZALO, C. Mastitis in small ruminants. Small Ruminant Research, 2007, vol. 68, n. 1-2, p. 145-153. http://dx.doi.org/10.1016/j.smallrumres.2006.09.011.

DAR, MD., TIWARI, DK., JHALA, SK., PATIL, DB., PARIKH, PV., JOY, N. and WADHWANI, KN. Ultrasonography of teat in surti goats. Indian Journal of Animal Research, 2014, vol. 48, n. 1, p. 59-62. http://dx.doi.org/10.5958/j.0976-0555.48.1.012. 
DescoteAuX, L., GNeMMI, G. and COLLOTON, J. Principles and recommendations, essential concepts, and common artifacts in ultrasound imaging. In DESCOTEAUX, L., GNEMMI, G. and COLLOTON, J. (Eds.). Practical atlas of ruminant and camelid reproductive ultrasonography. USA: Blackwell Publishing, 2010. p. 3-12.

DYCE, KM., SACK, WO. and WENSING, CJ. Textbook of veterinary anatomy. 4th ed. Philadelphia: W.B. Saunders, 2010. p. 721-727.

FASULKOV, IR., GEORGIEV, PI., ANTONOV, AL and ATANASOV, AS. B-mode ultrasonography of mammary glands in goats during lactation period. Bulgarian Journal of Veterinary Medicine, 2010, vol. 13, p. 245-251

FASULKOV, IR., VASILEV, N., KARADAE, M. and DINEVA, G. Visualization and measurement of teat structures in Black and White cows through ultrasonography. Mac Vet Rev, 2014, vol. 37, n. 1, p. 89-93. http://dx.doi.org/10.14432/j.macvetrev.2014.02.010.

FASULKOV, IR., YOTOV, S., ATANASOV, A. and ANTONOV, AL. Evaluation of different techniques of teat ultrasonography in goats. journal of the Faculty of Veterinary Medicine, Istanbul University, 2013, vol. 39, n. 1, p. 33-39.

GARRETT, PD. Guide to ruminant anatomy based on the dissection of the goat. 1st ed. USA: Iowa State University Press, 1988. p. 47-51.

HALLOWELL, GD. Ultrasound of the bovine mammary gland and its role in mastitis control. Dairy Topics, 2012, vol. 11, n. 5, p. 41-43.

HAMED, A., MABROUK, MM., SHAAT, I. and BATA, S. Estimation of genetic parameters and some non-genetic factors for litter size at birth and weaning and milk yield traits in zaraibi goats. Egyptian Journal of Sheep \& Goat Sciences, 2009, vol. 4, n. 2, p. 55-64.

HILDEBRAND, M. Anatomical preparations. California: University of California Press, 1968. p. 7-10.

HUSSAIN, S.S., LONE, T. and MOULVI, B.A. Regional and surgical anatomy of bovines. 1st ed. India: International book distributing, 2009. p. 213-222.

JALAKAS, M., SAKS, P. and KLAASSEN, M. Suspensory apparatus of the bovine udder in the Estonian black and white Holstein breed increased milk production (udder mass) induced changes in the pelvic structure. Anatomia, Histologia, Embryologia, 2000, vol. 29, n. 1, p. 51-61. PMid:10820903. http://dx.doi.org/10.1046/j.14390264.2000.00245.x.

KONIG, HE. and LIEBICH, HG. Veterinary anatomy of domestic mammals, textbook and color atlas. 3rd ed. Stuttgart: Scattauer GmbH, 2009. p. 595-603.
MAY, NDS. The anatomy of the sheep. 3rd ed. Brisbane: University of Queensland press, 1971.p. 67-68.

MOUSSA, EAM. Age morphological changes of the goat's udder (Capra hircus). Ismailia: Faculty of Veterinary Medicine, Suez Canal University, 2003. p. 28-32. [Thesis].

INTERNATIONAL COMMITTEE ON VETERINARY GROSS ANATOMICAL NOMENCLATURE - ICVGAN. Nomina Anatomica Veterinaria - NAV. 5th ed. Ghent: ICVGAN, 2012.

QUTP, MMA. Studies on some surgical affections of the udder and teat of ruminants. Benisuef: Faculty of Veterinary Medicine, Beni-Suef University, 2014. p. 132-137. [Thesis].

RAGAB, G.A., SALEH, M.S., AHMED, A.S., ABEDEL-FATTAH, M. and SHAMAA, A. Ultrasonic mammography in goats. J Egypt Vet Med Ass, 1999, vol. 59, n. 2-3, p. 735-755.

RAMBABU, K., SREENU, M., KUMAR, RV. and RAO, TSC. Ultrasonography of the udder and teat in buffaloes. Buffalo Bulletin, 2009 , vol. 28 , n. 1, p. 5-10.

SEEH, C., HOSPES, R. and BOSTEDT, H. Use of visual methods (sonograph/endoscopy) for a diagnosis of a webbed teat in cattle. Tierärztliche Praxis, 1996, vol. 24, n. 5, p. 438-442. PMid:8999588.

SENDAG, S. and DINC, D. Ultrasonography of the bovine udder. Turkish Journal of Veterinary and Animal Sciences, 1999, vol. 23, p. $545-552$.

SLOSARZ, P., WOJTOWSKI, J., BIELINSKA, S., FRACKOWIAK, A., LUDWICZAK, A., KRZYSEWSKI, J., BAGNICKA, E. and STRZALKOWSKA, N. Machine induced changes of caprine teats diagnosed by ultrasonography. African Journal of Biotechnology, 2010, vol. 9, p. 8698-8703.

SMALLWOOD, J.E. A guide tour of veterinary anatomy, domestic ungulates and laboratory mammals. 1st ed. Philadelphia: W.B. Saunders, 1993. p. 109-122.

SMUTS, MMS. and BEZUIDENHOUT, AJ. Anatomy of the dromedary. Oxford: Clarendon Press, 1987. p. 221-222.

WOJTOWSKI, J, SLOSARZ, P, JUNKUSZEW, A, MILERSKI, M, SZYMANOWSKA, A. and SZYMANOWSKI, M. Application of ultrasound technique for cistern size measurement in dairy goats. Archiv fur Tierzucht Dum-merstorf, 2006, vol. 49, p. 382-388.

Received August 16, 2016 Accepted August 12, 2017 